\title{
A Simple Method for the Assay of Guinea Pig Anti-Insulin Serum
}

\author{
Peter H. Wright and Willy J. Malatsse
}

Department of Pharmacology, Indiana University Medical Center, Indianapolis, Indiana

Received August 3, 1966

\begin{abstract}
Summary. The insulin-binding potency of guinea pig anti-insulin serum (GPAIS) is determined following reaction for 30 minutes at room temperature between solutions containing GPAIS and mixtures of unlabeled and ${ }^{131} \mathrm{I}$ labeled insulin. Insulin which has not reacted with the antibodies is extracted from solution by a suspension of finely divided cellulose. From the radioactive contents of supernatant solutions from reaction mixtures containing the sample, an excess of non-precipitating (reference) GPAIS, and the buffered diluent, the potency of the sample can be determined. Factors affecting the assay procedure are considered and it is shown that, within defined limits, results are reproduceable and the method sensitive and rapid. The technique has potential uses for the study of insulin-antibody reactions and has practical applications in the production and rational use of GPAIS.
\end{abstract}

Une méthode simple pour la détermination des titres antiinsuliniques du sérum de cobaye.

Résumé. Les auteurs présentent une méthode pour l'estimation du pouvoir de liaison avec l'insuline, du sérum anti-insulinique, obtenu par immunisation de cobayes. Les solutions contenant l'immun-sérum sont incubées durant 30 minutes entre 20 et $25^{\circ} \mathrm{C}$, en présence d'un mélange d'insuline ordinaire et de radioinsuline- ${ }^{131} \mathbf{I}$. L'insuline libre, non liée aux anticorps, est extraite de la solution par addition d'une suspension de cellulose en fines particules. Le titre en anticorps d'un échantillon est calculé à partir des radioactivités mesurées dans les surnageants de trois différents milieux, contenant respectivement les anticorps à doser, un excès d'immun-sérum non-précipitant (sérum de référence) et le milieu tampon. Différents facteurs susceptibles d'interférer avec le dosage sont envisagés et la méthode est prouvée sensible, rapide et, endéans des limites définies, reproductible. Cette méthode peut être utilisée pour l'étude des réactions entre l'insuline et ses anticorps et a également trouvé un champ d'application dans la production et l'emploi rationnels du sérum anti-insulinique.

Eine einfache Methode zum Nachweis von Anti-InsulinSerum beim Meerschweinchen.

Zusammenfassung. Es wird berichtet über eine $\mathrm{Me}$ thode, die insulinbindende Kraft des Anti-Insulin-Serum beim Meerschweinchen (GPAIS) zu bestimmen. Die Lösungen, die das Immunserum enthalten, werden während $30 \mathrm{~min}$ bei einer Temperatur zwischen $20^{\circ}$ und $25^{\circ} \mathrm{C}$ inkubiert in Gegenwart einer Mischung von gewöhnlichem Insulin und mit ${ }^{131} \mathrm{I}$ markiertem Radioinsulin. Das freie Insulin, das nicht an Antikörper gebunden ist, wird aus der Lösung durch Hinzufügung einer Aufschwemmung von feinverteilter Zellulose extrahiert. Aus dem radioaktiven Gehalt der überstehenden Lösungen der Realktionsgemische, die die Probe, einen Überschuß von nicht präzipitierendem GPAIS (Bezugserum) und die gepufferte Verdünnungsflüssigkeit enthalten, läßt sich die insulinbindende Kraft bestimmen. Faktoren, die die Bestimmungsmethode beeinflussen können, werden diskutiert. Es läßt sich zeigen, daß die Ergebnisse innerhalb definierter Grenzen reproduzierbar sind, während die Methode empfindlich und schnell durchzuführen ist. Die Technik läßt sich mit Vorteil zum Studium der Reaktionen zwischen Insulin und seinen Antikörpern verwenden. Ihr praktischer Anwendungsbereich liegt in der Produktion und dem zweckmäßigen Gebrauch des Anti-Insulin-Serum.
Antibodies to insulin, and especially those produced by the guinea pig, have been the subject of several studies in recent years [21], but no simple and sensitive method has yet been described for their assay. Most attention has been focussed in the case of guinea pig anti-insulin serum (GPAIS) upon its use for the assay of insulin in blood [4], and for this purpose only an approximate knowledge of insulin binding capacity is required. For more definitive studies of the insulin antibodies themselves, two principal methods have been used. The first, introduced by ARQuILLA and Stavitsky [2], depends upon a direct effect of the antibodies upon red cells conjugated with insulin by means of bis-diazo benzidine; these are lysed or agglutinated according to the experimental conditions. The second involves the use of ${ }^{131} I$-labeled insulin and depends upon methods for the separation of free insulin from insulin bound in the form of insulinantibody complexes. This has been done by chromatoelectrophoresis on filter paper [5]; by fractional precipitation with salts [12], with cold solutions of salt in ethanol [11], and with antibodies specifically directed against globulins in the anti-insulin serum [24]; by chromatography on filter paper impregnated with ion exchange resins $[18,16]$; and by absorption of free insulin with charcoal coated with dextran [13]. All these methods have served the purposes of their various authors, but none has proved sufficiently simple and accurate for routine use in the study of insulin antibodies.

The present method, briefly reported elsewhere [28], is based on an old observation that cellulose in the form of filter paper will absorb "free" insulin from solution [31]; cellulose columns are reported to serve the same purpose [6]. It involves the use of ${ }^{131}$ I-labeled insulin and a suspension of finely divided cellulose. It is here used to assay quantities of GPAIS of the order of 1 to $10 \mu \mathrm{l}$ and eapable of binding 1 to $50 \mathrm{mU}$ insulin. It has been successfully used to assay small quantities of serum from individual guinea pigs undergoing immunization with insulin [27] and, in a modified form, to study insulin secretion in vitro [29] and in vivo [17] in the rat. 


\section{Materials and Methods}

Guinea pig anti-insulin serum (GPAIS). Serum containing antibodies to bovine insulin was obtained from guinea pigs by a method described elsewhere in detail [27, 22]. In most cases, sera from individual animals were pooled according to their potencies and either stored in the frozen state, or first lyophilized and then reconstituted by addition of distilled water. For incorporation into reaction mixtures, initial dilutions were carried out in buffer but when the degree of dilution exceeded $1: 10$, a buffered solution of albumin ( $1 \%$ BSA, see below) was used.

Insulin preparations. Stock solutions $(100 \mathrm{U} / \mathrm{ml})$ of two preparations of recrystallised bovine insulin (Lot No. CBI $4245 \mathrm{LL}, 22.2 \mathrm{U} / \mathrm{mg}$, Boots Pure Drug Company Limited, England; Lot. No. T 2842, 25.2 U/ $\mathrm{mg}$, Eli Lilly and Company, Indianapolis, U.S.A.) were prepared in dilute acetic acid $(3 \%, v / v$, glacial $)$ and stored in the frozen state. Radioactive ${ }^{131}$ I-labeled bovine insulin $(6-11 \mathrm{mc} / \mathrm{mg}$, Abbott Laboratories, North Chicago, Illinois) was diluted in 1\% BSA to give a stock solution (ca. $10 \mathrm{mU} / \mathrm{ml}$ ) which was also stored in the frozen state; such insulin was used within 2 weeks of receipt and arbitrarily assumed to have a potency of $25 \mathrm{U} / \mathrm{mg}$. For experimental use, these stock solutions were diluted in $1 \% \mathrm{BSA}$, the final ratio of labeled to unlabeled hormone in any insulin mixture exceeding $1 \%$ only where this is specifically mentioned.

Reagents. All experiments were carried out in neutral solutions ( $\mathrm{pH}, 7.0$ ) of phosphate buffer (Sorenson, $0.1 \mathrm{M}$ ) to which was added either normal guinea pig serum or ded in phosphate buffer and the suspension stirred continuously (magnetic stirrer). To ensure that equal amounts of cellulose in equal aliquots of suspension were added to each reaction tube, a single pipette $(1.0 \mathrm{ml})$ was used to transfer aliquots of the continuously stirred suspension. Also examined in a single experiment, were finely divided preparations of phosphorylated (MN $300 \mathrm{P}$ ), carboxymethyl (MN $300 \mathrm{CM}$ ), diethyl-amino-ethyl (MN $300 \mathrm{DEAE}$ ), and acetylated (MN $300 \mathrm{Ac}$ ) cellulose from the same commercial source. All these latter preparations of cellulose were first washed with buffer until the supernatent solutions were neutral $(\mathrm{pH}, 7.0-7.1)$, and then suspended in buffer $(10 \%, \mathrm{w} / \mathrm{v})$ for experimental use.

Experimental procedure. A basic procedure was developed for the assay of GPAIS and this was varied to study the experimental conditions under which it was carried out.

a) Basic procedure (Table 1, Expts. 1 and 8). Samples of GPAIS of either constant ( $10 \mu \mathrm{l}$; Expt. 8) or varying (0 to $100 \mu \mathrm{l}$; Expt. 1) volumes were diluted to a constant volume (usually $0.5 \mathrm{ml}$ ) in either buffer or $1 \%$ BSA. This diluted serum was allowed to react for 30 minutes with a constant volume $(0.5 \mathrm{ml})$ of insulin mixture containing a fixed amount of unlabeled (50 or $100 \mathrm{mU}$ ) and a trace (0.1 to $0.5 \mathrm{mU}$ ) of labeled insulin. The reaction was then stopped by addition of the cellulose suspension $(1.0 \mathrm{ml})$. A further 30 minutes later, and after intermittent agitation, the cellulose was deposited by centrifugation for 10 minutes in a elinical centrifuge. Equal aliquots of the resulting clear

Table 1. Experiments carried out to study conditions for the assay of guinea pig anti-insulin serum

\begin{tabular}{|c|c|c|c|c|c|c|c|}
\hline \multirow{3}{*}{$\begin{array}{l}\text { Expt. } \\
\text { No. }\end{array}$} & \multicolumn{4}{|c|}{ Reaction mixture } & \multirow{3}{*}{$\begin{array}{l}\text { Reaction } \\
\text { Time }\end{array}$} & \multirow{3}{*}{$\begin{array}{l}\text { Exposure } \\
\text { to } \\
\text { Cellulose } \\
\text { (min) }\end{array}$} & \multirow{3}{*}{$\begin{array}{l}\text { Radioactive } \\
\text { content } \\
\text { measured }\end{array}$} \\
\hline & \multirow{2}{*}{$\begin{array}{l}\text { Total } \\
\text { Vol. } \\
\text { (ml) }\end{array}$} & \multicolumn{2}{|l|}{ Insulin } & \multirow{2}{*}{$\begin{array}{l}\text { GPAIS } \\
(\mu 1)\end{array}$} & & & \\
\hline & & $\begin{array}{l}\text { Labeled } \\
(\mathrm{mU})\end{array}$ & $\begin{array}{l}\text { Enlabeled } \\
(\mathrm{mU})\end{array}$ & & & & \\
\hline 1 & 1.0 & $0.1-0.5$ & 50 or 100 & $0-100$ & 30 & 30 & $\mathrm{Su}$ \\
\hline 2 & 1.0 & 1.2 & 0 to 4000 & Nil & - & 30 & Su \\
\hline 3 & 1.0 & 0.5 & 50 & 0 to 50 & 30 & 5 to 60 & $\mathrm{Su}$ \\
\hline 4 & 1.0 & 0.5 & 50 & 0 to 50 & 3 to 120 & 30 & $\mathrm{Su}$ \\
\hline 5 & 1.0 & 0.005 & 0 to 20 & 1.0 & 30 & 30 & $\mathrm{Su}$ \\
\hline $6 \mathbf{a}$ & 1.5 & $0.1-0.5$ & 0 or 100 & 100 & 30 & 30 & TSu and $\mathrm{C}$ \\
\hline $6 \mathrm{~b}$ & 1.0 & 0.5 & 100 & 100 & 30 & 30 & $\mathrm{Su}$ \\
\hline $6 c$ & 1.0 & 0.5 & 100 & 100 & 30 & 30 & Su and $\mathrm{NC}$ \\
\hline 7 & 1.5 & 0.5 & 50 & 0 to 100 & 30 & Nil & $\mathrm{Su}$ \\
\hline 8 & 1.0 & 0.5 & 100 & 10 & 30 & 30 & Su \\
\hline
\end{tabular}

In each individual experiment, diluted GPAIS $(0.3-1.0 \mathrm{ml})$ was mixed with an insulin mixture $(0.5-1.0 \mathrm{ml})$ to give the same final volume of reaction mixture $(1.0-1.5 \mathrm{ml})$. After subsequent addition of a constant volume $(1.0 \mathrm{ml})$ of either the suspension of cellulose or buffer, radioactivity was measured in equal aliquots of supernatent solution (Su); in the whole of the supernatent solution (TSu) and washed deposit of cellulose (C); or in aliquots of the reaction mixture diluted with buffer (NC). Other details of individual experiments are given in the text or in sub-titles to the Figures and Tables.

bovine serum albumin $(1 \%, \mathrm{w} / \mathrm{v}$; Bovine Albumin, Fraction V, Sigma Chemical Company, St. Louis, Missouri); the buffered solution containing albumin is hereafter called $1 \% B S A$. Finely powdered cellulose $(10 \%$, w/v; MN 300; particle size less than $10 \mu$; Macherey, Nagel \& Co., Düren, Germany) was suspen- supernatant solution $(0.5$ or $1.0 \mathrm{ml})$ were then examined for radioactive content.

In addition to tubes containing samples of GPATS, control tubes contained ( $\mathrm{I}$ ), an excess (usually $0.1 \mathrm{ml}$ ) of a sample of GPAIS (reference serum; Lots 302,334 , or 335) capable of retaining in solution after exposure 
to cellulose all the radioactive material in the added insulin mixture; (II), 1\% BSA or appropriately diluted normal serum (blank tubes) from which all immunoreactive insulin is removed by cellulose leaving only degradation products of the labeled hormone in solution; and (III), the same constituents as the blank tube to which was added buffer $(1.0 \mathrm{ml})$ in place of the suspension of cellulose (no cellulose).

An automatic counter was used to measure $\beta$ - and $\gamma$-radioactivity (Tricarb Liquid Scintillation System, Series 3000, with attached well-type Scintillation detector, Model 5052; Packard Instrument Company, La Grange, Illinois). In individual experiments, all $\gamma$ radiation was measured in a constant volume $(0.5$ to $2.0 \mathrm{ml}$ ) of solution or suspension between 300 and 460 $\mathrm{mEv}$. For the measurement of $\beta$-radioactivity, aliquots of neutral solution (1 Volume; usually $0.5 \mathrm{ml}$ ) were added to a scintillation fluid (10 Volumes) similar to that described by BRAY [7]. Radioactivity was measured in equal aliquots of supernatant solution from tubes containing the samples of GPAIS $\left(C_{s}\right)$, the excess of reference serum $\left(C_{e x c}\right)$, the diluted normal serum or $1 \%$ BSA $\left(C_{b l}\right.$, blank $)$, or no cellulose $\left(C_{N C}\right)$. The amount of insulin bound by antibodies in the sample of GPAIS $\left(I_{s}\right)$ was calculated using the following equation:

$$
I_{s}=T I \times\left(C_{s}-C_{b l}\right) /\left(C_{e x c}-C_{b l}\right) .
$$

where $T I$ represents the total amount of insulin added to the sample.

b) Modified procedures used to study experimental conditions of assay (Table 1, Expts. 2 to 7). To simplify description of the results, the compositions of reaction mixtures and details of times of reaction and exposure to cellulose are shown in Table 1. Modifications of the basic procedure included the following:

I. In experiments Nos. 2 and 5, the amount of labeled hormone was kept constant and the unlabeled hormone varied. In both cases the insulin mixtures were prepared before addition of GPAIS (Expt. 5) or the cellulose preparations (Expt. 2).

II. The concentrations of non-specific protein (normal serum-proteins or bovine albumin) in final reaction mixtures lay between about 0.6 and $1.0 \%$. In experiment No. 5 , the protein content of the reaction mixture was varied, GPAIS $(1.0 \mu \mathrm{l})$ being diluted in buffer containing varying volumes $(0,3,19$, and $99 \mu 1)$ of normal guinea pig serum.

III. The time of exposure to cellulose was varied by centrifugation of the final suspension 5 to 60 minutes after addition of the cellulose (Expt. 3). To vary the time of reaction, samples of each reaction mixture $(1.0 \mathrm{ml})$ were added to equal volumes of cellulose suspension 3 to 120 minutes after admixture of GPAIS and the insulin mixture; centrifugation was carried out 30 minutes later.

IV. To estimate the radioactive contents of separated cellulose and supernatent solution, the supernatant solution was removed and the cellulose deposit washed 4 times with aliquots $(2.0 \mathrm{ml})$ of a solution identical with the supernatant solution but containing normal instead of anti-insulin serum (Expt. 6a). The supernatant solution and washings were combined and made up to the same final volume $(10 \mathrm{ml})$. An aliquot $(2.0 \mathrm{ml})$ of diluted supernatant solution and the deposit of cellulose suspended in an equal volume of buffer were used to determine the radioactive contents of the two phases.

V. Precipitation of insulin-antibody complexes was studied in duplicate series of reaction mixtures. To one series of tubes, cellulose suspension was added, and to the other, an equal volume of buffer (Expts. 1 and 7, respectively). Both series of tubes were centrifuged 30 minutes later and the radioactive contents of equal aliquots of supernatant solution compared.

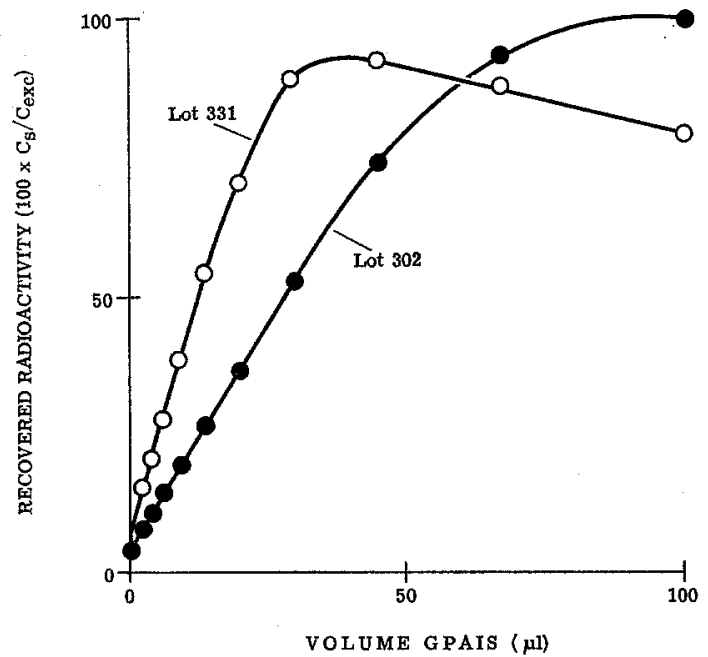

Fig. 1. Percentage of added radioactive material recovered in the supernatant solutions $\left(100 \times C_{s} / C_{e x c}\right)$ after reaction between varying volumes of GPAIS $(0-100 \mu \mathrm{l})$ and a constant mixture of unlabeled $(100 \mathrm{mU})$ and labeled $(0.5 \mathrm{mU})$ bovine insulin (Table 1, Expt. 1). Each point represents the mean of 5 (Lot 331) or 3 (Lot 302) observations

As shown in Table 1, radioactivity was finally measured in equal aliquots of supernatant solution $(S u)$; in the entire supernatent solution $(T S u)$ and washed deposit of cellulose $(C)$; or in aliquots of reaction mixtures diluted with buffer instead of the suspension of cellulose $(N C)$. All results, unless otherwise stated, are quoted as mean values with standard errors of those means. All values of $C_{e x c}$ were determined with GPAIS of Lots 302, 334, or 335 which had insulin binding capacities of 1.9, 2.1, and 2.3 Units insulin/ml serum, respectively. Recovery rates in supernatant solutions are stated as percentages of $(\mathrm{I})$, the total radioactive content of the added insulin mixture $\left[C_{T S u} /\left(C_{T S u}+C_{C}\right)\right.$; Table 2, Column a $]$; (II), the radioactive content of equal aliquots of supernatant solution from reaction mixtures containing an excess of reference serum $\left(C_{s} / C_{e x c}\right.$; Table 2, Column $\mathrm{b}$, and Fig. $1,2,3,5,6$ and 7 ); and (III), the insulin content of the original insulin mixture $\left[\left(C_{s}-C_{b l}\right) /\left(C_{e x c}-C_{b l}\right)\right.$; Table 3]. Details of other measurements of radioactivity (Table 2, Column e; Fig. 4 and 7) are given in the text under the heading of results. 


\section{Results}

Effect of dilution on insulin binding by GPAIS (Table 1, Expt. 1). The contrasting behaviours of two samples of GPAIS (Lots 302 and 331) are illustrated in added to the assay system; and (IV), that a linear relationship does exist between the amount of antibody in a sample of GPAIS and the amount of insulin which it will retain in solution after exposure to cellulose.

Table 2. Recovery of added radioactive material in solution after treatment with cellulose

\begin{tabular}{|c|c|c|c|c|c|c|}
\hline \multicolumn{4}{|c|}{ Reaction mixture } & \multicolumn{3}{|c|}{ Recovery rate (\%) } \\
\hline $\begin{array}{l}\text { GPAIS } \\
\text { Lot } \\
\text { No. }\end{array}$ & $\begin{array}{l}\text { Vol. } \\
(\mu 1)\end{array}$ & $\begin{array}{l}\text { Normal } \\
\text { Serum } \\
(\mu l)\end{array}$ & $\begin{array}{l}\text { Unlabeled } \\
\text { Insulin } \\
\text { (mU) }\end{array}$ & $\begin{array}{l}\text { (a) } \\
\text { Relative } \\
\text { to } \\
\text { Added } \\
\text { Radioactivity } \\
\end{array}$ & $\begin{array}{l}\text { (b) } \\
\text { Relative } \\
\text { to } \\
\text { Reference } \\
\text { Serum }\end{array}$ & $\begin{array}{l}\text { (c) } \\
\text { Relative } \\
\text { to } \\
\text { Diluted } \\
\text { Insulin } \\
\end{array}$ \\
\hline- & - & 100 & 100 & $\underset{(6)}{6.1} \pm 0.64$ & $\underset{(14)}{4.9} \pm 0.58$ & 一 \\
\hline - & - & - & 100 & - & $\begin{array}{r}4.0 \\
(11)\end{array} \pm 0.23$ & - \\
\hline 302 & 100 & - & 100 & $\begin{array}{l}98.3 \pm 0.01 \\
(6)\end{array}$ & 100 & $\begin{array}{l}110.0 \pm 1.3 \\
(14)\end{array}$ \\
\hline 302 & 100 & - & 0 & $\begin{array}{l}98.9 \pm 0.01 \\
(6)\end{array}$ & - & - \\
\hline 331 & 100 & - & 100 & $\begin{array}{l}85.5 \pm 0.36 \\
(4)\end{array}$ & $\begin{array}{l}80.0 \pm 1.65 \\
(8)\end{array}$ & $\begin{array}{l}85.3 \pm 3.6 \\
(4)\end{array}$ \\
\hline 334 & 100 & - & 100 & $\begin{array}{l}99.3 \pm 0.02 \\
(4)\end{array}$ & $\begin{array}{l}98.3 \\
(11)\end{array}$ & $\begin{array}{l}108.0 \pm 1.0 \\
(15)\end{array}$ \\
\hline
\end{tabular}

Insulin mixtures containing a trace of labeled insulin $(0.1-0.5 \mathrm{mU})$ were allowed to react with GPAIS $(100 \mu l)$, normal serum $(100 \mu \mathrm{l})$ or with diluent (1\% BSA) for 30 minutes (see Table 1, Expts. 6a, 6b, and 6c). Recovery of radioactive material (Mean) in supernatent solutions is quoted (Column a) as a percentage of the total amount present in the added insulin mixture $\left[100 \times C_{T S u} /\left(C_{T S u}+C_{C}\right)\right]$; (Column b), as a percentage of that found in equal aliquots of supernatent solution from reaction mixtures containing excess $(100 \mu \mathrm{l})$ of reference serum, Lot $302\left(100 \times O_{x} / O_{e x c}\right)$; and (Column c), as a percentage of the radioactivity found in equal aliquots of the insulin mixture diluted to the same final volume with $1 \% \mathrm{BSA}$ and buffer $\left(100 \times C_{s} / C_{N C}\right)$. The number of observations in each instance is shown in parenthesis.

Fig. 1. Of the total amount of radioactive material added, only a small fraction (ca. 5\%) was recovered in the supernatant solution of tubes containing no GPAIS. As the volumes of both samples of GPAIS were increased, the rates of recovery rose in what appeared to be a linear fashion until they reached values of 60 to $70 \%$. Further addition of one (Lot 302) resulted in continued but lesser increases until complete recovery $(100 \%)$ was achieved. In the other case (Lot 331), complete recovery was never achieved, the rate falling after a maximum value of $95 \%$ was attained. The behaviours of these two samples reflected extremes of those found with all other samples of GPAIS studied in the present investigations; they differed only under conditions in which GPAIS was present in excess. The consistent apparently linear relationship between the volume of added GPAIS and the rate of recovery of radioactive material when insulin was present in excess, suggested that this system could form the basis of a method of assay. The experiments outlined in Table 1 were therefore carried out to confirm (I), that cellulose will absorb from solution in 30 minutes all insulin which is not bound by antibodies in any reaction mixture; (II), that at room temperature, and under other specified conditions, reactions between insulin and the antibodies are complete in 30 minutes; (III), that samples of GPAIS can be found which in excess and after exposure to cellulose can retain in solution all radioactive material in insulin mixtures
Binding of insulin by cellulose and its derivatives (Table 1, Expts. 2 and 3). Of the total radioactive material added to comparable suspensions of the 5 preparations of cellulose, less than $5 \%$ remained in solution when either cellulose or DEAE-cellulose was added to insulin mixtures containing less than $800 \mathrm{mU}$ unlabeled insulin (Fig. 2). Carboxy-methyl and phosphorylated cellulose were less able to extract insulin from solution, and even in the absence of any unlabeled insulin, acetylated cellulose could only extract about half.

As shown in Fig. 3, no radioactive material was extracted from solution during 60 minutes of exposure to cellulose of mixtures containing an excess $(50 \mu \mathrm{I})$ of a sample of reference serum. In the absence of GPAIS $(0 \mu \mathrm{l})$, a constant low rate of recovery of less than $5 \%$ was established in 5 minutes. Between these two extremes, constant rates of recovery were established in 20 to 30 minutes as the volume of added GPAIS (6 and $12 \mu \mathrm{l}$ ) was increased.

It was concluded that cellulose in the amounts used here $(0.1 \mathrm{~g})$ will absorb from solution up to $800 \mathrm{mU}$ insulin in 30 minutes.

Conditions of reaction. Reactions between insulinand the antibodies in GPAIS'occur more slowly atlow temperatures $\left(0-4^{\circ} \mathrm{C}\right)$, and labeled insulin is degraded more rapidly at high temperatures (e.g. $\left.36^{\circ} \mathrm{C}\right)$. Also, the reaction does not appear to be affected by $\mathrm{pH}$ over a wide range about neutrality $(6.0-8.5)$. All reactions were therefore 
carried out at room temperature $\left(20-25^{\circ} \mathrm{C}\right)$ and a neutral buffer $(\mathrm{pH}, 7.0)$ was arbitrarily chosen. Only two factors were considered closely:

I. Time of reaction (Table 1, Expt. 4). When the suspension of cellulose was added to reaction mixtures

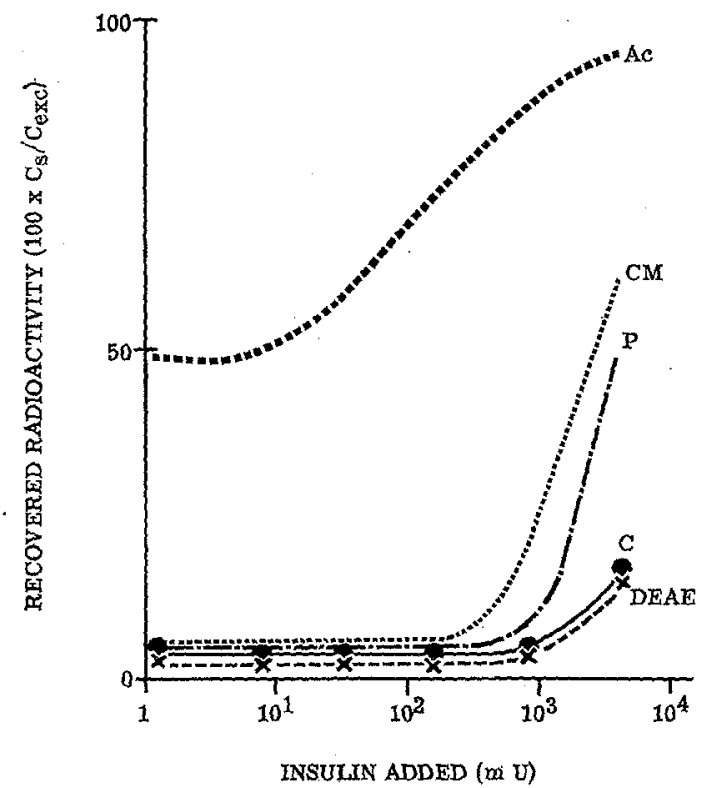

Fig. 2. Percentage of added radioactive material recovered in the superna tant solution $\left(100 \times C_{s} / C_{6 x c}\right) 30$ minutes after exposure of variable amounts of unlabeled $(0-10000 \mathrm{mU})$ and a constant amount of labeled $(1.2 \mathrm{mU})$ insulin to suspensions containing the same quantities $(0.1 \mathrm{~g})$ of cellujose (C) diethyl-axinoethyl (DEAE), phosphorylated (P), catroxy-methyl (OM and acetylated (Ac) celluloses (Table 1, Expt. 2)

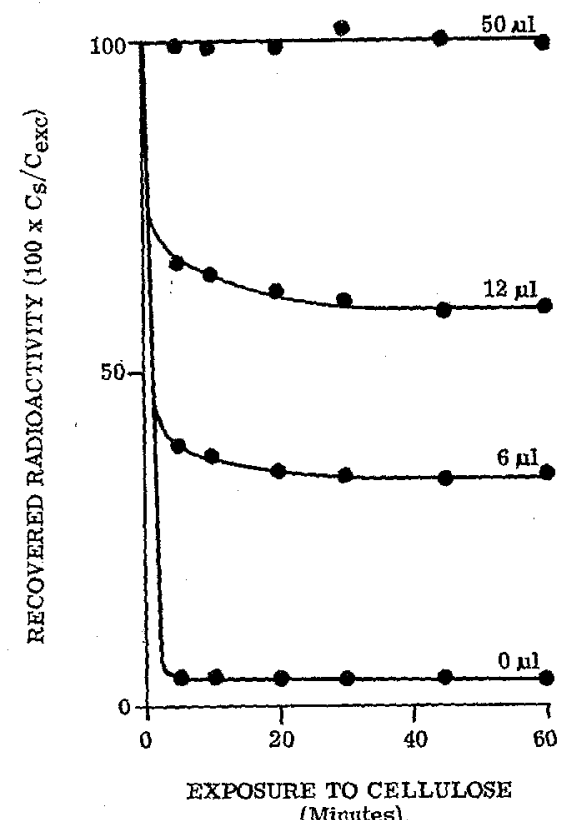

Big. 3. Percentage of added radioactive material recovered in the supernatant solution $\left(100 \times C_{s} / C_{\text {exc }}\right\}$ following reactions for 30 minutes between GPAIS (Lot 335, 50 $\mu$; Lot 400,6 and $12 \mu$ ) and a mixture contaíning a constant amount of unlabeled insulin (50 mU), and subsequent exposure to the auspension of cellujose for 5 to 60 minutes (Table 1, Expt. 3). Complete recovery $(100 \%)$ corresponds to the mean of the 6 values obtained with the excess of reference serum (Ijot $335 ; 50$ pil)
3 to 120 minutes after admixture of GPAIS and the insulin mixture, recovery of radioactive material in the supernatant solution rose sharply in the first 3 minutes (Fig. 4). Between 30 and 120 minutes, no signifieant increase in recovery could be detected at any level of addition of GPAIS.

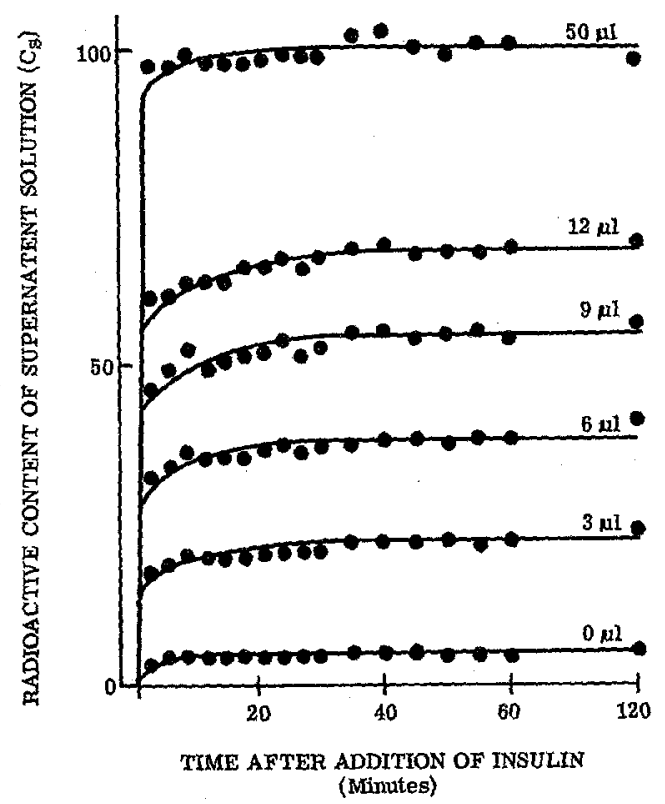

Fig. 4. Radioactive contents $(C s)$ of aliquots of supernatent solution after constant volumes of each reaction mixture $(1.0 \mathrm{ml}$ ) were added to an equal volume of cellulose suspension 3 to 120 minutes after admixture of an insulin mix ture ( $50 \mathrm{mU}$ unlabeled $+0.5 \mathrm{mU}$ labeled) to varying volumes of GPAIs (Lot $335,50 \mu \mathrm{l}$; Lot $400,3,6,9$; and $12 \mu \mathrm{l})$. Maximum recovery $\left(C_{\mathrm{s}}=100 \%\right.$ ) corresponds to the mean radioactive content of the 8 supernatant solutions derived from reaction mixtures containing the excess of reference serum (Lot 335; $50 \mu \mathrm{l}$ ) and treated with cellulose after more than 30 mintues of reaction (see Table 1, Expt. 4)

II. Non-specific proteins (Table 1, Expt. 5). When a constant volume of GPAIS $(1.0 \mu 1)$ was incubated with insulin in the presence of varying volumes of normal guinea pig serum, maximum recovery of added radioactive material occured when the reaction mixture contained the smallex amounts of unlabeled insulin (less than $1 \mathrm{mU}$ ) and the larger volumes ( 19 and $99 \mu \mathrm{l}$ ) of normal guinea pig serum (Fig. 5). When normal guinea pig serum was absent $(0 \mu l)$ or present in only a small amount ( $3 \mu l)$, no such maximum rate of recovery was noted at any level of addition of insulin. Complete recovery $(100 \%)$ was never achieved, probably because the time of reaction (30 minutes) was insufficient at these low concentrations of insulin and GPAIS.

Reactions between insulin and an excess of GPAIS. In the above experiments, it was assumed that, when present in excess, GPAIS retains in solution all the labeled material in the added insulin mixtures. This assumption was investigated in the following series of experiments (Table 1, Expts. $6 \mathrm{a}, 6 \mathrm{~b}$ and $6 \mathrm{c}$ ):

I. Separation of cellulose from supernatant solution. Total recovery of added radioactivity from the supernatant solution and deposit of cellulose was complete 
$(101+0.4 \%)$ in these experiments (Expt. 6a). When the initial reaction mixture contained normal serum, only $6 \%$ could be recovered in the supernatant solution (Table 2, Column a), and less than half of this could be precipitated with trichloracetic acid $(10 \%, w / v)$. More

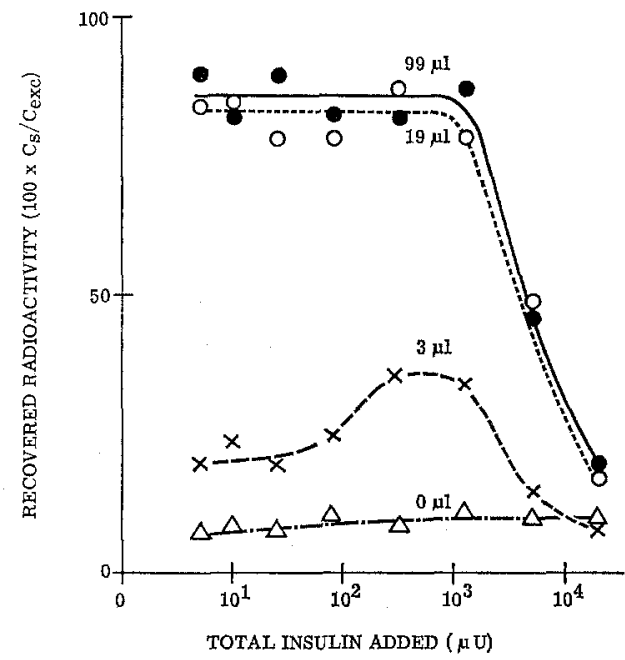

Fig. 5. Percentage of added radioactive material recovered in the supernatant solution $\left(100 \times C_{s} / C_{e x c}\right)$ derived from reaction mixtures containing GPAIS $(1.0 \mu \mathrm{l})$ and variable volumes of normal serum $(0,3,19$, and $99 \mu \mathrm{I})$ with a constant amount of labeled $(5 \mu \mathrm{U})$ and variable quantities of unlabeled $(0$ to $20 \mathrm{mU}$ ) insulin, all diluted in buffer. Maximum recovery $(100 \%)$ eorresponds to the value of $C_{\text {exc }}$ for an excess of reference serum (Lot 302 $0.1 \mathrm{ml}$ ). In the absence of GPAIS recovery remained at 4 to $6 \%$ irrespective of the amount of unlabeled insulin (Table 1, Expt. 5)

than $98 \%$ was found in the supernatant solution derived from two specimens of GPAIS (Lots 302 and 334 ), and in one of these cases (Lot 302) it made no difference whether unlabeled insulin was present in the insulin mixture or not. The third sample (Lot 331), however, was only able to retain $85 \%$ of the added radioactive material in solution. In each case where GPAIS was used, more than $95 \%$ of the radioactive material in the supernatant solution was precipitable with trichloracetie acid.

II. Comparison of supernatant solutions. Knowing that one sample of GPAIS (Lot 302), in excess, could bind all added radioactive material in solution, the radioactive contents of supernatant solutions obtained with this serum were compared with those of others studied under similar conditions (Expt. 6b). As seen in Table 2 (Column b), one sample (Lot 334) proved as effective in excess as the reference serum but the second (Lot 331) again retained only $80 \%$ of the added labeled material in solution. By contrast, the supernatant solutions from reaction mixtures which inchuded the same volume $(100 \mu \mathrm{l})$ of normal serum diluted in buffer or only $1 \% \mathrm{BSA}$, contained less than $5 \%$ of the added radioactive material.

If all added radioactive material cannot be retained in solution, the value of $C_{\text {exc }}$ cannot be determined and it is not possible to calculate by the present method the amount of insulin bound by antibodies in samples of GPAIS. To find samples of GPAIS with properties similar to those of serum of Lot 302,48 sera were incubated under the conditions outlined above (Expt. 6 b). As shown in Fig. 6, only 7 were able to concentrate

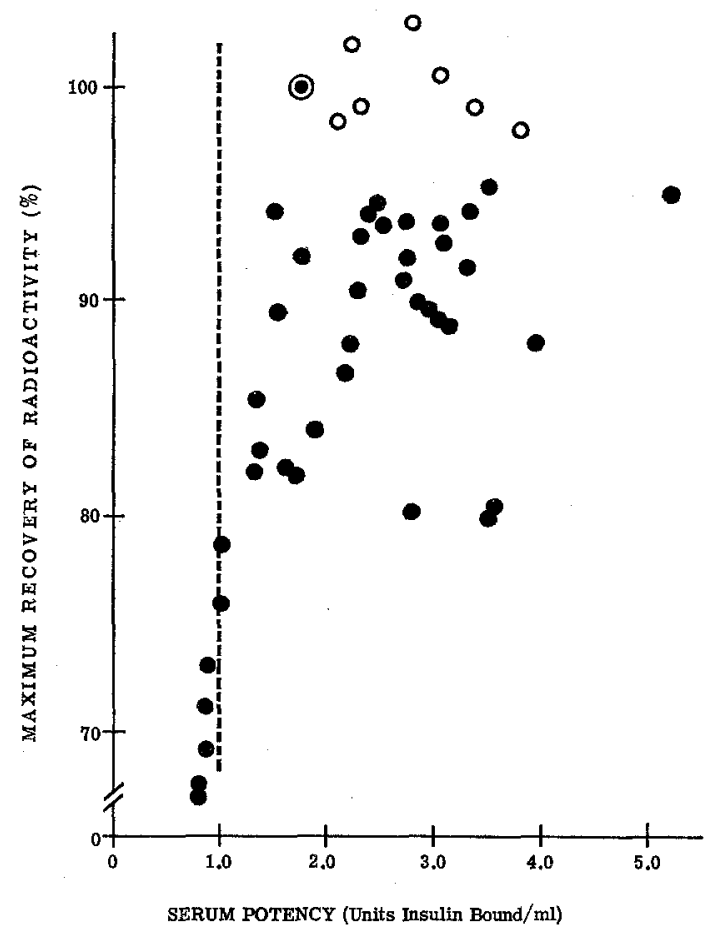

Fig. 6. Percentage of added radioactive material recovered in the super natant solution $\left(100 \times C_{s} / C_{e x c}\right)$ after incubation for 30 minutes of the same volumes $(100 \mu \mathrm{l})$ of 48 samples of GPAIS with the same insulin mixture (100 $\mathrm{mU}$, unlabeled $+0.5 \mathrm{mU}$ labeled). Recovery is plotted against the potency of each serum determined in a separate experiment (Table 1 Fxpt.8.) Maximum recovery $(100 \%)$ was determined using the same volume $(100 \mu \mathrm{l})$ of reference serum (Lot 302) which is shown by the large circle. Sera suitable for reference are shown as smalier open circles. Each point represents the mean of 3 determinations of potency and recovery (Table 1, Expt. $6 \mathrm{~b}$ )

more than $97 \%$ of the added radioactive material in solution (Lots 311, 334, 335, 344, 389, 390 and 393), and all of these were more potent than the GPAIS used for reference (Lot $302 ; 1.9$ Units insulinbound/ml). Less than $97 \%$ of the added radioactive material remained in solution using the same volumes $(100 \mu \mathrm{l})$ of 26 other sera, 14 of which were less potent than the reference sample. Of these 14 sera, 7 were not capable of binding all the added insulin since their potencies were too low (binding less than 1.0 Units insulin/ml).

To explain the behaviours of sera such as GPAIS of Lot 331, duplicate reaction mixtures were treated with either the suspension of cellulose (Table 1, Expt. 1) or an equal volume of buffer (Table 1, Expt. 7), the radioactive contents of supernatent solutions in both series of tubes being compared after centrifugation 30 minutes later (Fig. 7). As expected (af. Fig. 1), all added radioactive material remained in solution after mixtures containing an excess of one sample of GPAIS (Lot 334) had been exposed to cellulose. In the other case (Lot 331), however, recovery declined when the volume of added serum exceeded $30 \mu \mathrm{l}$. When buffer was added in place of the cellulose suspension, all the 


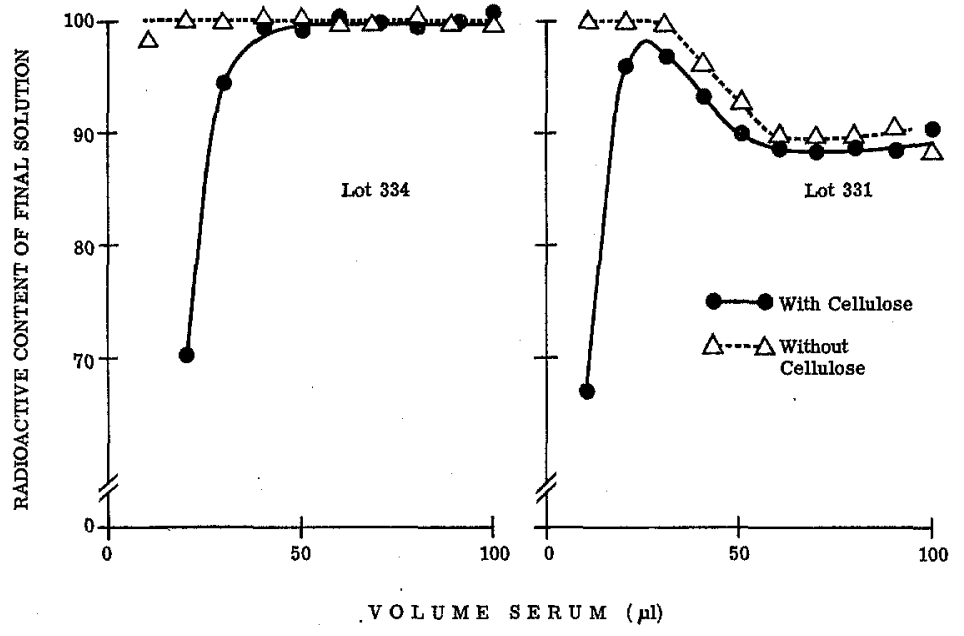

Fig. 7. Radioactive contents of aliquots of solution obtained after reaction between variable volumes of GPAIS (Lots 334 and $331 ; 10$ to $100 \mu \mathrm{l}$ ) and a constant insulin mixture ( $50 \mathrm{mU}$ unlabeled $+0.5 \mathrm{mU}$ labeled); and subsequent addition of either buffer $(1.0 \mathrm{ml})$ or the same volume of cellulose suspension. In both cases, final mixtures were centrifuged after 30 minutes. Maximum recoveries correspond to values of $C_{e x c}$ and $C_{N C}$ obtained for reaction mix tures containing excess of the reference serum (Lot 334, $100 \mu \mathrm{l})$. For experimental conditions, see Table 1, Expts. 1 and 7

added radioactive material remained in solution at all levels of addition of the one serum (Lot 334). In the other case (Lot 331), recovery again fell once a minimum volume of serum had been added (ca. $30 \mu \mathrm{l}$ ) and flocculent precipitates were clearly visible in all tubes containing more than this volume. No precipitates were seen in any tube containing normal serum or the other sample of GPAIS (i.e. Lot 334). It was concluded, therefore, that when all added radioactive material is not retained in solution by an excess of anti-insulin serum, some of the insulin antibody complex must be precipitated.
III. Use of diluted insulin mixtures. Cellulose occupies a finite but undetermined volume in the final suspension from which the supernatent solution is sampled. If all added radioactive material remains in solution, then its concentration in this supernatant solution should be greater than that to be found in the same sample of insulin mixture diluted to the same final volume with buffer or 1\% BSA (Table 1, Expt. 6c). As shown in Table 2 (Column o), the ratio was found to be about 1.10 when the radioactive contents of supernatant solutions containing excess reference serum (Lots 302 and 334) were compared with those in the diluted insulin mixture. When the precipitating serum (Lot 331) was used, however, the ratio was much lower (0.85). This comparison is useful for two reasons. First, such a control (No cellulose) can be used to establish rapidly whether a sample of GPAIS is suitable for use as a reference serum; if, under the conditions used here, the ratio is less than 1.05 , this is unlikely. Secondly, it allows calculation of the volume of fluid displaced by the cellulose; from the results shown in Table 2 (Column c), it was calculated that cellulose displace almost twice its own weight of fluid $(0.17 \pm$ $0.01 \mathrm{ml} / 0.1 \mathrm{~g}$ cellulose).

Relationship between insulin recovery in the supernatant solution and volume of incubated GPAIS. The foregoing experiments showed that, with the aid of a suitable sample of GPAIS (reference serum), it is possible to concentrate all added radioactive material in solution ( $C_{\text {exc }} \equiv 100 \%$ recovery). If it is assumed that cellulose only absorbs immunologically active labeled insulin, then it is also possible to determine the

Table 3. Recovery of insulin in supernatant solution after addition of a constant amount of insulin to varying volumes of anti-insulin sera

\begin{tabular}{|c|c|c|c|c|c|c|c|}
\hline \multirow{3}{*}{$\begin{array}{l}\text { Lot No. } \\
\text { Insulin } \\
\text { add. (mU) } \\
\text { Assays. } \\
\text { Volume } \\
\text { serum: } \\
\text { (ul) }\end{array}$} & \multirow{2}{*}{$\begin{array}{r}302 \\
100\end{array}$} & \multicolumn{2}{|l|}{270} & \multicolumn{2}{|l|}{331} & \multicolumn{2}{|l|}{334} \\
\hline & & 50 & 100 & 50 & 100 & 50 & 100 \\
\hline & 3 & 10 & $\mathbf{5}$ & 4 & 5 & 3 & 6 \\
\hline 100.0 & 100.0 & $96.0 \pm 0.8$ & $98.5 \pm 1.8$ & $78.9 \pm 1.5$ & $77.6 \pm 3.3$ & $103.0 \pm 1.5$ & $100.5 \pm 1.2$ \\
\hline 66.7 & $92.9 \pm 3.4$ & $97.0 \pm 2.0$ & $92.4 \pm 1.8$ & $83.3 \pm 2.7$ & $86.7 \pm 1.1$ & $106.0 \pm 2.0$ & $99.4 \pm 1.4$ \\
\hline 44.4 & $73.4 \pm 4.3$ & $95.7 \pm 1.7$ & $79.2 \pm 1.1$ & $85.9 \pm 2.3$ & $91.8 \pm 1.6$ & $106.0 \pm 2.0$ & $79.4 \pm 1.9$ \\
\hline 29.6 & $51.0 \pm 3.0$ & $84.5 \pm 1.7$ & $59.2 \pm 2.0$ & $95.1 \pm 2.6$ & $88.6 \pm 1.5$ & $99.7 \pm 3.0$ & $57.0 \pm 0.9$ \\
\hline 19.8 & $34.6 \pm 2.3$ & $65.2 \pm 1.1$ & $39.9 \pm 0.8$ & $96.3 \pm 2.6$ & $68.2 \pm 2.2$ & $78.2 \pm 2.7$ & $40.4 \pm 1.2$ \\
\hline 13.2 & $24.1 \pm 1.9$ & $46.4 \pm 0.7$ & $27.9 \pm 0.7$ & $88.3 \pm 3.9$ & $48.6 \pm 2.1$ & $56.6 \pm 2.6$ & $27.3 \pm 0.8$ \\
\hline 8.8 & $16.5 \pm 1.6$ & $32.2 \pm 0.8$ & $18.7 \pm 0.6$ & $65.7 \pm 3.4$ & $34.2 \pm 1.3$ & $40.3 \pm 2.1$ & $18.4 \pm 0.6$ \\
\hline 5.9 & $11.4 \pm 1.0$ & $22.9 \pm 0.7$ & $12.3 \pm 0.6$ & $47.5 \pm 2.6$ & $23.9 \pm 0.7$ & $27.9 \pm 1.3$ & $12.4 \pm 0.6$ \\
\hline 3.9 & $7.3 \pm 0.7$ & $14.9 \pm 0.7$ & $8.4 \pm 0.4$ & $33.1 \pm 1.3$ & $15.5 \pm 0.6$ & $19.2 \pm 1.1$ & $8.1 \pm 0.5$ \\
\hline 2.6 & $4.9 \pm 0.4$ & $10.1 \pm 0.4$ & $5.5 \pm 0.3$ & $22.5 \pm 1.0$ & $10.1 \pm 0.3$ & $13.4 \pm 0.7$ & $5.2 \pm 0.5$ \\
\hline 1.7 & & $6.6 \pm 0.3$ & & $15.3 \pm 0.9$ & & $9.2 \pm 0.8$ & \\
\hline 1.2 & & $4.7 \pm 0.2$ & & $11.1 \pm 0.3$ & & $5.8 \pm 0.3$ & \\
\hline
\end{tabular}

Varying volumes $(0-100 \mu \mathrm{l})$ of 4 samples GPAIS (Lots 270, 302, 331, and 334) were incubated with constant amounts of unlabeled (50 or $100 \mathrm{mU}$ ) and a trace of labeled insulin (Table 1, Expt. 1). Recovery (Mean) of insulin in supernatent solutions after treatment with cellulose is stated as a percentage of the amount added $\left[100 \times\left(C_{s}-C_{b l}\right) /\right.$ $\left.\left(C_{e x c}-C_{b l}\right)\right]$. Complete recovery in each experiment was achieved using an excess (100 $\left.\mu 1\right)$ of the same sample of reference serum (Lot 302). 
proportion of added radioactive material which is not associated with insulin (i.e. $C_{b l}$ ). The proportion of added insulin which is bound by antibodies in any sample of incubated GPATS can therefore be determined $\left[\left(C_{s}-C_{b l}\right) /\left(C_{e x c}-C_{b l}\right)\right]$. Using serially diluted samples of 4 specimens of GPAIS (Lots 270, 302, 331, and 334 ) at two rates of addition of insulin (50 and $100 \mathrm{mU}$ ), rates of insulin recovery (quoted as percentages) were determined for the same volumes (1.2 to $100 \mu \mathrm{l}$ ) of each (Table 3). Since results shown in Fig. 1 suggested a linear relationship over this range, the findings reported in Table 3 were analysed statistically to establish a linear relationship between recovery rates of less than $65 \%$ and the corresponding volumes of incubated GPAIS. The results of this analysis are summarized in Table 4 which shows that at each rate of addition of insulin, a significant linear relationship does exist $(p<0.01)$ for all four sera; and that in each case the Co-efficient of Correlation $(r)$ is almost unity $(0.984-0.995)$. It can also be seen that the intercept of each mean Regression Line $(a, x=0$ ), though significantly different from zero in some instances, is small; always less than $4 \%$, but usually about $1 \%$.
Assay of insulin antibodies in GPAIS. Based on these findings, two methods were used to determine the insulin binding potencies of the 4 sera shown in Table 3.

I. Serial dilution of individual sera. Using the mean Regression Co-efficients and Intercepts (Table 4), the volumes of each serum $(x, \mu l)$ which could theoretically bind all added insulin $(y=100 \%)$ were calculated. From these volumes, shown in Table 4, and the known quantities of unlabeled insulin added in each case, (50 or $100 \mathrm{mU}$ ), the insulin binding potency of each serum was calculated (Table 5). It is seen that the $95 \%$ Confidence Iimits fall 2 to $5 \%$ on either side of each calculated mean value. In a single experiment of this type it has also been estimated that the $95 \%$ Confidence Limits would fall 7 to $15 \%$ on either side of the mean calculated potency.

II. Assay of single samples. The linearity of the relationship between recovery of added insulin and the volume of incubated GPAIS and the small value of the intercepts shown in Table 4, suggest that under conditions in which less than $65 \%$ of the added hormone is recovered, the antibodies in GPAIS behave

Table 4. Relationship between volume of incubated GPAIS and recovery of "insulin in the supernatant solution

\begin{tabular}{|c|c|c|c|c|c|c|c|}
\hline \multirow[b]{2}{*}{$\begin{array}{l}\text { GPAIS } \\
\text { Lot } \\
\text { No. }\end{array}$} & \multirow[b]{2}{*}{$\begin{array}{l}\text { Insulin } \\
\text { added. } \\
\text { (mU) }\end{array}$} & \multicolumn{4}{|c|}{ Linear relationship } & \multicolumn{2}{|c|}{ Value of $x$ at $y=100 \%$} \\
\hline & & $\begin{array}{l}\text { Regression } \\
\text { Coefficient } \\
\left(b \neq s_{b}\right)\end{array}$ & $\begin{array}{l}\text { Intercept } \\
(a)\end{array}$ & $\begin{array}{l}\text { Significance } \\
(p)\end{array}$ & $\begin{array}{l}\text { Co-eff. } \\
\text { Correl. } \\
(r)\end{array}$ & $\begin{array}{l}\text { Mean. } \\
(\mu l)\end{array}$ & $\begin{array}{l}\text { Confidence } \\
\text { Interval. } \\
(95 \%) \\
\end{array}$ \\
\hline 270 & 100 & $1.98 \pm 0.03$ & 0.88 & $<0.01$ & 0.995 & 50.05 & $48.81-51.30$ \\
\hline 302 & 100 & $1.70 \mp 0.04$ & 1.09 & $<0.01$ & 0.986 & 58.29 & $55.80-60.79$ \\
\hline 331 & 100 & $3.62 \pm 0.09$ & 1.41 & $<0.01$ & 0.985 & 27.20 & $26.07-28.34$ \\
\hline 334 & 100 & $1.93 \pm 0.02$ & $0.99 *$ & $<0.01$ & 0.988 & 51.29 & $50.36-52.22$ \\
\hline 270 & 50 & $3.49 \pm 0.04$ & $1.08^{*}$ & $<0.01$ & 0.991 & 28.32 & $27.81-28.83$ \\
\hline 331 & 50 & $7.22 \pm 0.23$ & $3.55^{*}$ & $<0.01$ & 0.984 & 13.36 & $12.70-14.02$ \\
\hline 334 & 50 & $4.21 \pm 0.09$ & $2.18 *$ & $<0.01$ & 0.991 & 23.23 & $22.40-24.06$ \\
\hline
\end{tabular}

The results shown in Table 3 were analysed statistically using the volumes of incubated GPAIS ( $x \mu$ l) and corresponding rates of insulin recovery $(y \%)$ with mean values of less than $66 \%$. Details of the calculated linear relationships $(y=a+b x)$ include the mean Regression Co-efficients $\left(b \pm s_{b}\right)$; the mean intercept of each Regression line $(\alpha ; x=0)$ and values significantly different $(p=0.05)$ from zero shown with an asterisk (*); the statistical significance of each linear correlation $(p)$ and each Co-efficient of Correlation $(r)$. The volumes of each serum capable (theoretically) of binding all added insulin in each series of experiments ( $x$ for $y=100 \%$ ) were calculated from the mean Regression Coefficients and intercepts and are shown here with the Confidence Intervals for each Mean value $(95 \%)$.

Table 5. Insulin binding capacities (Units/ml) estimated with single samples and serially diluted anti-insulin sera

\begin{tabular}{|c|c|c|c|c|c|c|c|c|}
\hline \multirow{2}{*}{$\begin{array}{l}\text { Lot } \\
\text { No. }\end{array}$} & \multicolumn{2}{|c|}{ Insulin added } & \multicolumn{2}{|c|}{ Serial dilution } & \multicolumn{4}{|c|}{ Single sample } \\
\hline & $(\mathrm{mU})$ & $\mathbf{n}$ & Mean & 95\% C.I. & $\begin{array}{l}\text { Volume } \\
\text { (uI) }\end{array}$ & $\mathbf{n}$ & Mean & $95 \%$ C.I. \\
\hline 270 & 100 & 5 & 2.00 & $1.95-2.07$ & $13.2^{*}$ & 5 & 2.10 & $1.95-2.25$ \\
\hline 302 & 100 & 3 & 1.72 & $1.65-1.80$ & 10.0 & 35 & 1.90 & $1.84-1.95$ \\
\hline 331 & 100 & 5 & 3.68 & $3.55-3.98$ & $13.2 *$ & 6 & 3.62 & $3.26-3.98$ \\
\hline 334 & 100 & 6 & 1.95 & $1.92-1.98$ & 10.0 & 19 & 2.13 & $2.07-2.19$ \\
\hline 270 & 50 & 10 & 1.77 & $1.74-1.80$ & $8.8^{*}$ & 13 & 1.90 & $1.80-2.00$ \\
\hline 334 & 50 & 3 & 2.16 & $2.08-2.24$ & $8.8^{*}$ & 3 & 2.27 & $1.54-2.90$ \\
\hline
\end{tabular}

The mean insulin-binding capacities (Units insulin/ml) of the 4 samples of GPAIS and Confidence Intervals for each $(95 \%)$ were calculated from the observations $(a)$ obtained by serial dilution of each and shown in Tables 3 and 4 ; and $(b)$ made with single samples of each (Table 1, Expt. 8). The numbers of observations made in these two series of experiments $(n)$ refer to the number of experiments carried out with serial dilution of each sample (see Table 3); and the number of individual small samples of each which were assayed. Single samples marked with an asterisk (*) were individual samples referred to in Table 3; the others were examined during routine assays. 
in a homogeneous manner. In other words, recovery of added insulin in the supernatant solution can be taken to be directly proportional to the antibody content of the incubated sample of GPAIS. Thus:

Insulin binding capacity (Units insulin $/ \mathrm{ml}$ ) =

$$
\frac{\text { Insulin added }(\mathrm{mU})}{\text { GPAIS incubated }(\mu \mathrm{l})} \times \frac{\left(C_{s}-C_{b l}\right)}{\left(C_{e x c}-C_{b l}\right)}
$$

In routine assays, constant volumes $(10 \mu \mathrm{l})$ of two samples of GPAIS (Lots 302 and 334) were incubated with the same amount of insulin $(100 \mathrm{mU})$. In other cases shown in Table 5 , individual values have been taken from the results shown in Table 3 . In each case, the above equation has been used to calculate the insulin binding potencies of the sera. As shown in Table 5, potencies determined by this method are equally reproduceable, the Co-efficients of Variation ranging between 6 and $12 \%$ and usually being less than $10 \%$. The $95 \%$ Confidence Limits fall less than $10 \%$ on either side of each mean calculated value except in those cases where few observations were made (Lots 331 and $334 ; 50 \mathrm{mU}$ added insulin). Using a value of $10 \%$ for the Co-efficient of Variation, a high figure during routine assays in our experience, 6 observations would be sufficient to obtain $95 \%$ Confidence Limits falling within $10 \%$ on either side of the mean calculated potency.

In addition to being reproducable, these two methods of assay give results which are comparable on an absolute basis. Potencies determined using single samples of the same volume are, if anything, slightly higher than those obtained on serial dilution of a serum.

\section{Discussion}

The technique outlined above for the assay of guinea pig anti-insulin serum is very similar to that recently described by HERBERT, LAU, GoTTLIEB and BLEICHER [13]; they used charcoal coated with dextran of a specified molecular weight (80000) to absorb insulin from solution. The technical simplicity of the present method depends upon the use of a preparation of cellulose which is sufficiently finely divided to allow pipetting of the suspension. Its reproduceability depends, in part at least, upon the sample of GPAIS used for reference; it should retain in solution all added radioactive material in the insulin mixture. Over two years it has proved conspicuously free of technical "snags" and has been shown to have practical value in studies involving the use of GPAIS.

For the assay of insulin in plasma, cellulose, in the form of filter paper, has long been used to separate free insulin from insulin bound to antibodies in GPAIS; the free insulin in any mixture remains fixed to the paper at its point of application, the bound hormone migrating on chromato-electrophoresis with the globulins [4]. Using this technique, Berson and YALOW [5] and Morst [20] were able to make quantitative studies of reactions between insulin and the insulin antibodies produced by various species. For the assay of antibodies to insulin in human serum, MTTCHELL and BRADFORD [18] found filter paper less effective for the chromatographic separation of free and bound insulin than filter paper impregnated with ion exchange resins. No detailed information has been published on the use of cellulose itself, though BERSON and YaLow [6] do refer to unpublished work in which they used chromatography on columns of cellulose. Such columns have been used extensively for the purification of iodinated insulin. When crude preparations of ${ }^{131}$ I-labeled insulin are passed through columns of cellulose, degradation products of the iodinated hormone and iodide may be washed through with buffer. Pure immuno-reactive labeled insulin, as judged by various criteria, remains adherent to the cellulose but can be eluted with undiluted normal (non-immune) serum. In reporting this, YALOW and BERSON [31] were careful to point out that only a portion of the labeled hormone is eluted by this method. In experiments of the present type in which large volumes of serum $(0.5 \mathrm{ml})$ were used for the assay [28], more of the added radioactive material $(8.31 \pm$ $1.07 \% ; n=17$ ) was retained in solution by normal serum than by the smaller volumes $(0.1 \mathrm{ml} ; 4.9 \%)$ or by the diluent solution of albumin (1\% BSA, $4.0 \%)$ used in blank tubes in the present experiments (Table 2). The latter small fractions of the total added radioactive material, most of which was soluble in trichloracetic acid, could not be further reduced by omission of all protein from the solution. It is considered to represent "damaged" or degraded labeled insulin and inorganic iodide which do not react with the antibodies in GPAIS. Subtraction of this fraction $\left(C_{b l}\right)$ from the total radioactive content of supernatant solutions $\left(C_{s}\right.$ and $\left.C_{e x c}\right)$ therefore seems warranted in determining radioactivity due to immunologically competent labeled insulin. This can only be justified, however, if the blank tubes contain non-specific proteins in low concentrations such as those used here $(0.6-1.0 \%)$. With higher concentrations of non-specific protein in the reaction mixture, part of the radioactive material retained in solution could represent insulin "bound" to non-specific protein.

The selection of a suitable sample of GPAIS for reference is of prime importance; any precipitation which it induces would result in over-estimation of potency. The findings shown in Fig. 6 suggest that such sera are rare, but this conclusion is probably erroneous. Most of the 48 tested samples of GPAIS were composed of serum from animals bled at various stages of immunization over periods up to 2 years and pooled according to potency. Among them were three (Lots 389, 390 and 393) from animals bled less than 3 months after their first injections of insulin. Unlike sera obtained from the same animals at later stages of immunization, these sera behaved like the reference sera used throughout the present experiments (i.e. Lots 302,334 , and 335 ); in excess, they retained in solution more than $97 \%$ of the added radioactive material in the insulin mixture. The nature of the precipitate formed by sera 
such as Lot 331 was not investigated. Like those reported by Hirata and BlUMenthaL [14], they formed rapidly and at room temperature. A longer period of incubation ( 2 days) and lower temperature $\left(4^{\circ} \mathrm{C}\right)$ were used with the same effect by JoNes and CUNLIFEE [15]. Both of these latter groups showed that maximum precipitation oceurs at an optimal ratio of serum to insulin; above and below this optimal ratio, precipitation decreases rapidly. In the present experiments (Fig. 7), precipitation was observed only when GPAIS was present in excess and none was erer detected when insulin was in excess. Precipitation can, therefore, interfere with determinations of $C_{e x c}$ but is unlikely to affect determinations of potency when GPAIS is incubated with an excess of insulin.

There is abundant evidence to show that GPAIS contains a heterogeneous collection of insulin antibodies $(4,21,22,23,24)$. This is also apparent in the present system under conditions where more than 60 to $70 \%$ of the added insulin is bound by antibodies. The present techniques could be applied to the study of this heterogeneity for the reactions between insulin and the antibodies can be controlled at every stage, and stopped at will by the addition of cellulose. Such heterogeneity of the antibodies is not apparent when less than about $60 \%$ of the added insulin is bound (Fig. 1). Under these conditions reproduceable estimates of insulin binding potency, comparable with those obtained in vivo in rats [28], can be obtained rapidly and with little technical dfficulty. From the immediate practical point of view, therefore, this technique offers a useful means for the selection of guinea pigs likely to yield potent anti-insulin serum [27]; for determining the amount of GPAIS needed to induce insulin deficiency in an experimental animal [25, 9]; to counteract the effects of insulin in any medium in which insulin sensitive tissue is to be incubated $[26,10,1,23]$; or to select a sample of GPAIS for use in one or other of the methods for the assay of insulin in plasma [31, 19]. It has also been found (unpublished) that after neutralization of less than $60 \%$ of the antibodies with unlabeled insulin, it is possible to use the same method for estimation of residual reactive insulin antibodies in GPAIS. This modification of the present system requires further investigation, but it has already provided useful information about insulin secretion from the rat's pancreas in vivo [29] and in vitro [17]. It seems, therefore, that the present technique not only offers the possibility of a simple and reproduceable method for the study of reactions between insulin and antibodies, but also, within well defined limits, a simple method for the assay and hence rational use of guinea pig anti-insulin serum.

Acknowledgements. The authors wish to acknowledge grants in aid of this research (PHS AM 07211), assistance from the Research Computation Center at this $\mathrm{Me}$ dical Center (PHS FR 00162-02), and a Post-doctoral Fellowship (1 FO 5-TW-865-01) for one of us (W.M.). Our thanks are also due to Boots Pure Drug Company
Limited, England, and Eli Killy and Company, Indianapolis, for generous supplies of recrystallised bovine insulin; to Dr. Pao-Lu YU and Mr. H.M. BRtTtarn for advice and assistance with the statistical analyses; and to $\mathrm{Mr}$. L. Norman, Mr. S. Grewr, and Miss Jean Poser for skilled technical assistance willingly given over a period. of two years.

\section{References}

[1] Antontades, H.N., J.A. Bougas, R. CamerintDavalos and H.M. PYLE: Insulin regulating mechanism and diabetes mellitus. Diabetes 13, 230-240 (1964).

[2] ArQumla, E.R., and A.B. Stavitsky: The production and identification of antibodies to insulin and their use in assaying insulin. J. clin. Invest. 35, 458466 (1956).

[3] - , and J. FInN: Insulin antibody variations in rabbits and guinea pigs, and multiple antigenic determinants on insulin. J. exp. Med. 118, 55-71 (1963).

[4] BersoN, S.A., and R.S. YaLow: Immunoassay of protein hormones. In "The Hormones". (PIncus, G., K.V. Thumann and E.B. Astwood, Eds.) Vol. IV, New York, Academic Press, pp. 557-630, 1964.

[5] - - Quantitative aspect of the reaction between insulin and insulin-binding antibody. J. clin. Invest. $38,1996-2016$ (1959).

[6] - - Recent studies on insulin binding antibodies. Ann. N. Y. Acad. Sci. 82, 338-344 (1959).

[7] BRAY, G.A.: Liquid scintillator for counting aqueous solution in a liquid scintillation counter. Analyt. Biochem. 1, $279-285$ (1960).

[8] Concos, J.M., and Z. OVARY: Biological properties of guinea pig anti-insulin antibodies. Proc. Soc. exp. Biol. 119, 142-148 (1965).

[9] Franckson, J.R.M., Y. ARNould, W. Mataisse and V. Corard: Glucose metabolism in the normal anesthetised dog injected successively with anti-insulin serum and insulin. Diabetes 13, 532-541 (1964).

[10] Fromsch, E.R., H. Burgi, E. B. Ramseter, P. Bally and A. LabHant: Antibody suppressible and nonsuppressible insulin-like activities in human serum and their physiological significance. An insulin assay with adipose tissue of increased precision and specificity. J. clin. Invest. 42, 1816-1834 (1963).

[11] Gords, E.: Detection of insulin-binding antibodies and separation of free and antibody bound insulin by rapid chemical procedure. Proc. Soc. exp. Biol. 103, $542-544(1960)$.

[12] Gronsky, G. M., and P.H. ForshaM: Immunochemical assay of total extractable insulin in man. J. clin. Invest. 39, 1070-1079 (1960).

[13] Herbert, V., K.S. LaU, C.W. GotTuteb and S.J. BumrCHer: Coated charcoal immunoassay of insulin. J. clin. Endocr. 25, 1375-1384 (1965).

[14] Hrmata, Y., and H.T. BuUmenthat: Demonstration of precipitating insulin-binding antibody in the serum of insulin treated guinea pigs and rabbits. J. Lab. clin. Med. 62, 683-691 (1963).

[15] Jones, V.E., and A.C. CunLIFF: A precipitating antibody to insulin. Nature. 192, 136-138 (1961).

[16] Kologet, Y., L. L. Wiesel, V. Posttano and G.E. ANDERSON: An immune chromatographic method for assay in serum of antibodies to glucagon and insulin. Proc. Soc. exp. Biol. 112, 518-523 (1963)

[17] Malaisse, W.J., F. Malaisse and P.H. Wright: A new method for the measurement in vitro of pancreatic insulin secretion. Endocrinology. in press.

[18] Mtтchel, M.L., and A.H. BradFord: The measurement of insulin binding by resin paper in vitro. Diabetes. 12, 257-261 (1963).

[19] Morgan, C.R., and A. Lazarow: Immunoassay of insulin: two antibody system. Plasma insulin levels 
in normal, sub-diabetic and diabetic rats. Diabetes $12,115-126(1963)$.

[20] MoRse, J.H.: Heterogeneity of insulin-antibody complexes in rabbits and guinea pigs. Proc. Soc. exp. Biol. 103, 494-496 (1960).

[21] Pope, C.G.: The immunology of insulin. In "Advances in Immunology". (DixoN, F.J., and J.H. Humphrex, Eds.), Vol. 5, New York, Academic Press, pp. 209-244, 1966.

[22] Robinson, B.H.B., and P.H. Wrigre: Guinea pig anti-insulin serum. J. Physiol. 155, 302-310 (1961).

[23] Samaan, N., R. Frazer and W.J. Dempster: The "typical" and "atypical" forms of serum insulin. Diabetes 12, $339-348$ (1963).

[24] Skom, J.H., and D.W. TALIIAGE: Non-precipitating insulin antibodies. J. clin. Invest. 37, 783-786 (1958).

[25] WRrght, P.H.: Experimental diabetes induced by insulin antibodies. In "On the nature and treatment of diabetes", (WREnshaLI, G.A., and B.S. LeIBEL, Eds.) New York, Excerpta Medica Foundation, pp. $354-360,1965$.

[26] - The effect of insulin antibodies on glucose uptake by the isolated rat diaphragm. Biochem. J. 71, 633638 (1959).

[27] - , and L. Normar: Some factors affecting insulin antibody production in guinea pigs. Diabetes. in press.

[28] -, and L.R. Catmum: Assay of insulin antibodies produced by the guinea pig. Nature 207, 995-996 (1965).

[29] - - and W.J. MaLAISse: Endogenous insulin secretion in the rat following injection of anti-insulin serum. Amer. J. Physiol. in press.

[30] Yagi, Y., P. Mater and D. Pressmar: Two different anti-insulin antibodies in guinea pig antisera. $\mathrm{J}$. Immunol. 89, 442-451 (1962).

[31] YALOW, R.S., and S.A. BERSON: Immunoassay of endogenous plasma insulin in man. J. clin. Invest. $39,1157-1175(1960)$.

Peter H. Wright and

WruLy J. Malatsse

Department of Pharmacology

Indiana University Medical Center

Indianapolis, Indiana, U.S.A. 